\title{
A FRANCISCAN FRIAR'S LETTER FROM THE CRIMEA (1287)
}

\author{
SzILVIA KovÁCs* \\ Research Group for Turcology, \\ Hungarian Academy of Sciences (MTA) - University of Szeged (SZTE) \\ H-6722 Szeged, Egyetem u. 2, Hungary \\ e-mail: kovszi@tvn.hu
}

From the second half of the 13th century, the Franciscan Order had played an important role in missionary activities in the Mongol Empire. The present paper investigates the Franciscans' role based on a letter written in 1287 by a Franciscan friar from the Crimea (frater Ladizlaus custos de Gazma) in which he described the events of recent years. For example, he reported on the baptism of a certain "Yaylaq", identified as a wife of Noghay, in the Crimea. In this paper, the historical background of this letter will be analysed with an emphasis on the relationship between the Franciscan order and the Golden Horde and the role of Yaylak Khatun's conversion in this process.

Key words: Franciscans, missionaries, Golden Horde, Nogay, Yaylaq.

The starting point of my paper is a letter written by a Franciscan friar Ladislaus, Guardian (Custos) of the Crimea, in Caffa (today Feodosiya in the Crimea) on the 11th of April 1287. The recipient of the letter was another Franciscan friar, Laurencius, who was sent to the West to the minister general of the Franciscan Order. In his letter Ladislaus informs his brother Laurencius, who had left the Crimea some time in 1286, about the events of the previous year. Thus, the letter comprises valuable pieces of information about the relationship between the Golden Horde and the Franciscan Order.

The great Mongol campaign between 1236 and 1241 radically changed the situation in the south Russian steppe in many respects. The Mongols and the peoples conquered by them had become exposed to a variety of religious influences. Western Christian missionaries also appeared in the south Russian steppe. The Dominican friars already had missions among the Cumans who lived in the steppe area between

* This publication was supported by the János Bolyai Research Scholarship of the Hungarian Academy of Sciences. 
the Volga and the Lower-Danube. As a consequence of the large-scale acts of conversion, the bishopric of the Cumans was established in Milcov in 1228 (Altaner 1924; Ferenţ 1931; 1981; Kovács 2009; Makkai 1936; Pfeiffer 1913; Spinei 2008). The localisation of Milcov remains a debated problem, because it disappeared after of the Mongol invasion. According to written sources, it was somewhere in Moldavia in today's Romania (Spinei 2008). The Franciscans started missions in the territory of the Mongol Empire probably only in the second half of the 13th century.

In this paper I will analyse the missionary activities of the Franciscans in the south Russian steppe and the relationship between the Franciscan order and the Golden Horde until 1287. The first Franciscan friars (Plano Carpini, Benedictus Polonus, C. de Bridia) passed through the territory of the Golden Horde as papal messengers as early as 1245, but their enterprise was essentially diplomatic in character (Dawson 1980 [1955], pp. 3-72; Jackson 2005, p. 256; Önnerfors 1967; Wyngaert 1929, pp. 27-143). However, word spread within Western Europe that there were Christians among the Mongols and certain members of the imperial family harboured Christian sympathies. The first Franciscans, who had conversion intentions, properly speaking, were William of Rubruck and Bartholomew of Cremona. On his return, Rubruck presented a precise report to King Louis IX. In this report he recognised his failure and he wrote: "I regard it as inadvisable for any friar to make any further journeys to the Tartars, as I myself did or as the Preaching Friars are doing" (Dawson 1980 [1955], p. 220; Jackson 1990, p. 278; Wyngaert 1929, p. 331).

The Franciscan friars were not discouraged by Rubruck's failure, as it is testified by the Hungarian provincial minister's letter. He reported to Pope Nicholas III (r. 1277-1280) on the large number of conversions effectuated by the friars and asked the Pope to re-establish the bishopric of Milcov mentioned before. In 1279 pope Nicholas III wrote to Philip the Fermo, his legate in Hungary, and asked him to examine the situation of the bishopric and report about it (Theiner 1859, p. 337). To our knowledge the report has never been made due to the situation in the Hungarian Kingdom (Szücs 2002, pp. 387-445).

From the sporadic data culled from different sources we can conclude that there were successful Franciscan missionary activities going on in the territories of the Golden Horde up till 1287. But we do not know exactly when the Franciscans appeared as missionaries and when their institutions were established in the SouthRussian steppe. Nor is it clear where they started their evangelistic enterprise. According to some scholars the Franciscans got a iarlyk from Möngke Temür khan (r. 12661280) in 1267, when the khan issued a iarlyk to metropolitan Kirill (DeWeese 1994, p. 97; Pelliot 1949, pp. 58-59; Richard 1977, p. 93; Ryan 2001, p. 154). This iarlyk was confirmed by Özbek khan (r. 1312-1341) in 1314 granting privileges to the Friars Minor (Bihl-Moule 1924, p. 65; Hautala 2014, pp. 35-36). According to other opinions the Vicariate of "Northern Tartary" (Vicaria Tartariae Aquilonaris) was established in the 1270s, due to the missionary achievements of Franciscan friars (Balanyi 1925, p. 72; Liščak 2012, p. 31). ${ }^{1}$ In 1287 the Vicariate of Northern Tartary did cer-

\footnotetext{
${ }^{1}$ Vicariates are ecclesiastical provinces in missionary regions.
} 
tainly exist. It was formed of two custodies, the first being Khazaria (Custodia Gazariae), including Crimea, the lower Danube region and lower Transnistria, and the second was Sarai (Custodia Sarayae), the eastern part of the Golden Horde, including the North Caucasus (Golubovich 1913, pp. 444-445; Redlich 1894, pp. 248-250). ${ }^{2}$

The two custodies from the Vicariate of "Northern Tartary" are mentioned for the first time in a letter written by custos Ladislaus. In those days the vicariate had five friaries in the territory of the south Russian steppe: Solkhat (Eski Qirïm), Kerqueti (Qirq Yer), Caffa, Saray and Vicum. Three of them were in the Crimean peninsula, the fourth was near the Volga river and the fifth was somewhere at the lower Danube. It is not excluded that further "mobile convents" may have existed at that time. But we have records of them only from the 14 th century onward. In a letter written in "a Tartar camp in Bascardia" in 1320, a Hungarian Franciscan who calls himself Brother Iohanca reports to his superior that the friars who worked in the "mobile convents" were far more successful than others in gaining converts (Bihl-Moule 1924, p. 67). In his chronicle (Liber Historiarum) from 1335 John Elemosina stated that the Franciscan friars had five convents in the cities and another five mobile convents in the second half of the $1270 \mathrm{~s}^{3}$ Clearly, the Franciscans started a successful expansion between 1278 and 1287.

Now we may return to the Crimean custos's letter. According to the letter the Muslims demolished the Franciscans' church and destroyed the bell in Solkhat (Eski Qïrïm) in 1285 or $1286 .{ }^{4}$ Therefore the Franciscan friars sent a messenger to the rulers of the Golden Horde. At that time Telebuga (r. 1287-1291) was the khan, but there was another powerful man, Nogay, the warlord of the westernmost territories of the Golden Horde. ${ }^{5}$ He played an increasingly important role in the history of the Golden Horde from 1260 to 1300 (Vásáry 2005, p. 71). ${ }^{6}$

In his letter Ladislaus wrote that their brother Moyse had returned from the court of the khan ("frater Moyses redierit de curia imperatoris"), where he was very efficient and could rightly declare his mission successful. Namely Telebuga khan and Nogay had sent three envoys to Solkhat, two of which were entrusted to punish the destroyers of the church and bell. The third, special envoy ("ambasiatorem specia-

${ }^{2}$ A Franciscan custody is a subdivision of a province presided by a custos.

3 "Ubi [in Tartaria Aquilonari - SzK] per fratres Minores decem loca edificata, V in civitatibus, et $\mathrm{V}$ in exercitibus et campestriis pascualibus inter Tartaros manent, predicantes et baptizantes et sacramenta sancte ecclesie conversis et fidelibus ministrantes... Inter istos Tartaros pastores gregum, fratres minores Sancti Francisci habent quinque loca mobilia in papilionibus filtro coopertis, et cum Tartaris moventur de loco ad locum, in curribus portantes loca et libros et ustensilia, qui Tartaris predicant et baptizant et administrant credentibus sacramenta" (Golubovich 1913, p. 125).

${ }^{4}$ The ringing of the bells seems to have been a perennial problem between the Christian and Muslim communities on the Crimean peninsula. See the iarlyk of Özbek khan (Bihl-Moule 1924, p. 65) and the letters of Pope John XXII from 1318 and 1323 (Baronius 1880, pp. 73, 202203).

${ }^{5}$ He was not a khan, but he became the absolute overlord of the westernmost territories of the Golden Horde, which stretched from the river Don as far as the Lower Danube (Vásáry 2005, pp. 88-91).

${ }^{6}$ For Nogay, see (Vásáry 2005, pp. 69-91). 
lem"), who was a Muslim ("esset Sarracenus"), arrived in Solkhat in August 1286. $\mathrm{He}$ entered the town with the cross and royal insignia and banners much to the delight of the Christians. The Muslims fled from the town to the neighbouring forests. The third envoy put three bells in the church. According to the friar's letter Nogay's wife, Yaylak khatun ("Iaylak imperatrix, maior et potencior uxor Nohay") arrived in Solkhat in those times. She did not only visit the Franciscans' church, but she also asked the friars to be baptised in the town of Qïrq Yer [Чуфут-Кале; Çufut Qale] ("voluit in civitate que vocatur Kerqueti baptizandi"). The Franciscan friars fulfilled her will gladly and the khatun was baptised in the presence of the members and leaders of the other Christian communities ("archiepiscopo Armenorum cum universo suo clero nec non et Gregorum sacerdotibus et clericis quampluribus"). The Franciscan friars got further favours from the Christian khatun: they received a friary in Qïrq Yer. The same lady appointed for them a protector, Ymor son of Molday, who had to protect the Franciscan friars from any injury on the part of the Saracens (Golubovich 1913, pp. 444-445).

On the basis of the letter I would like to draw attention to several points. Firstly, we do not know exactly when the Franciscan friars started their missions in the Crimea or in the territory of the Golden Horde. The Franciscan Rubruck passed the Golden Horde in 1253, but he did not mention his brethren's presence (Dawson 1980 [1955], pp. 89-220; Jackson 1990, pp. 59-278; Wyngaert 1929, pp. 164-331). In 1278 they were present in the south Russian steppe in such large numbers that they needed a bishop who could consecrate priests for them (Theiner 1859, p. 337). In 1287 the Vicariate of "Northern Tartary" had already existed with two custodies.

Secondly, the Franciscan friars, who were unimportant for the ruler of the Golden Horde until then, received serious support. The representatives of Telebuga and Nogay penalised the Muslims who had destroyed their church. The church of the Franciscans was rebuilt and the friars received new bells. So it is apparent from the letter that the Mongol treatment of the Franciscans exceeded the level of the usual Mongol religious tolerance. ${ }^{7}$ Brother Ladislaus reported of a new kind of support, namely the Franciscan order received factual subsidies from the Mongols.

Thirdly, the main wife of Nogay was baptised by the Franciscan friars in the presence of the representatives of the other Christian churches. It seems that Nogay, himself a Muslim, gave priority to the Franciscan order as against the Armenian and Byzantine churches. There is no evidence to indicate when the event happened, but it probably took place in the $1250 \mathrm{~s}$. We have data about Nogay's possible conversion to Islam from 1262/3 (Vásáry 2005, p. 71). At that time Nogay already had a Christian wife, as he had married Euphrosina, the illegitimate daughter of the Byzantine emperor Michael VIII Palaiologos (r. 1259-1282) (Failler-Laurent 1984, pp. 242-243). Thus, the conversion of Yaylak khatun does not suggest that Nogay supported the Christians in general, but mainly the Latin Christians.

${ }^{7}$ For the religious tolerance in the Mongol World Empire, see the recent work by Atwood (2004, pp. 237-256). 
Fourthly, who is exactly Yaylak mentioned in the letter? Her appellation imperatrix 'empress' (in this case it means khatun) and her epithets maior 'greater' and potencior 'mightier' suggest that she was the main wife of Nogay. Her name appears in Muslim (Arabic and Persian) sources as Baylak ${ }^{8}$. According to the account of Rašīd al-Dīn (Blochet 1911, pp. 145-150; Thackston 1999, pp. 364-365; Tizengauzen 1941, pp. 70-72), al-Nuwayrī (Tizengauzen 1884, pp. 136-137*, 157-158) and Baybars al-Manșūrī (Tizengauzen 1884, pp. 86-87*, 108-109) she played an important role in Nogay's political activities. For example, in 1293 Nogay sent his wife as an envoy and sent a message from her to Toqta khan (r. 1291-1312) asking the khan to liquidate some 23 noyons 'tribal chieftains' (Tizengauzen 1884, pp. 86*, 136-137*, $108-109,157-158)$. According to the written sources it is clear that Yaylak was a powerful woman who took part in political life and internal affairs. Though it cannot be excluded that Yaylak's conversion to Christianity was her personal decision, she inevitably needed her husband's permission for it, so her conversion denoted a political support for the Franciscan friars. ${ }^{10}$

Finally, if we delve into the possible causes and the motivation of Yaylak's conversion and her husband's support, the political efforts of Nogay become apparent. It is likely that supporting the Franciscans can be interpreted as a reconciliation with the Latin Church. Nogay was seen as an enemy of Christianity in the papal court for his attacks against the Hungarian Kingdom (1285) and the Polish territories (12861287). ${ }^{11}$ Apparently, Nogay's support for the Franciscan friars was aimed at improving his relations with the Papacy, thereby wanting to strengthen his power in Eastern Europe (Tănase 2004-2005, p. 296). Another motive of the rulers of the Golden Horde in creating a balanced relation with the Papacy was their conflict with the Persian Ilkhanids (Spuler 1965, pp. 69-71; Vásáry 1986, pp. 98-114). On the other hand, in Solkhat a mosque was started to be built in 1287, which denoted Nogay's far-seeing religious policy to create an equilibruim among religions. Despite his support for the Franciscans he did not want to bring Islam into a disadvantageus position in favour of Christianity. Another cause for his orientation toward Islam was the fact that Mamluk Egypt was the most important potential ally of the Golden Horde against the Ilkhanids. Friendly relationship with the Golden Horde was also essential for Mamluk Egypt to protect the source of supply of the slaves as well as the routes over which they were imported to Egypt. Seeing from this angle it is apparent why the Mamluk sultan al-Manșūr Qalāwūn (r. 1279-1290) sent costly material to furnish the mosque constructed in the Crimea (i.e. Solkhat) in 1287 (Tizengauzen 1884, pp. $\left.356^{*}, 363\right) .^{12}$

Although the popes and the rulers of the West saw in Nogay a potential ally against and a counterbalance to the Muslim Mamluks and the Ilkhanid Empire, Nogay

\footnotetext{
${ }^{8}$ The difference between the initial forms of Arabic $y(-)$ and $b(\hookrightarrow)$ is only one dot below.

${ }^{9}$ The asterisks refer to the original text, the subsequent page numbers to the translation.

${ }^{10}$ For Yaylak, see Pelliot (1949, pp. 73-79).

${ }^{11}$ For these campaigns, see Székely (1988, pp. 52-88); PSRL II (pp. 888-902).

${ }^{12} \mathrm{Ibn}$ al-Furāt reported that the Mamluk sultan al-Manșūr had dispatched stone masons, paints and painters to Solkhat (Tizengauzen 1884, pp. 356*, 363).
} 
did not manage to establish good relations with the Papacy despite the Franciscan friars' mediation (Tănase 2004-2005, p. 301).

In conclusion, the missionaries of the Franciscan Order probably appeared in the territory of the Golden Horde in the late 1250s. At first the Franciscan missionaries did not get support from the rulers of the Golden Horde (albeit they were not persecuted) and managed to establish their institutions. The Vicariate of Northern Tartary with two custodies already existed in 1287 and the Franciscan Order had several friaries in the cities of the Golden Horde. In the same year the Franciscans in the Crimea gained subsidy from the khans. In addition, the rulers of the Golden Horde favoured and gave preference to the Franciscan friars as opposed with other Christian congregations in the Crimean Peninsula. All this was part of Nogay's political strategy.

As can be seen from the letter of Ladislaus custos, the Franciscan friars were seemingly aware of the importance of these manifestations and benevolent acts of Nogay and Yaylak. They clearly realised that Yaylak's conversion was extremely significant, since it yielded a unique opportunity for the Franciscans for further missionary activities among the Mongols which could have opened the door to the conversion of the Mongol ruling class to Christianity.

\section{References}

Altaner, B. (1924): Die Dominikanermissionen des 13. Jahrhunderts. Forschungen zur Geschichte der kirchlichen Unionen und der Mohammedaner- und Heidenmission des Mittelalters. Habelschwerdt.

Atwood, P. Ch. (2004): Validation by Holiness or Sovereignty: Religious Toleration as Political Theology in the Mongol World Empire of the Thirteenth Century. The International History Review Vol. XXVI, No. 2 (June), pp. 237-256.

Balanyi, Gy. (1925): Adatok a ferencrendiek tatárországi missziós müködésének történetéhez [Some data on the history of the missionary activities of the Franciscans in Tartaria]. Katholikus Szemle Vol. 39, No. 2, pp. 70-84.

Baronius, C. (1880): Annales ecclesiastici 1313-1333. Tom. XXIV. Parisiis.

Bihl, M.-Moule, C. (1924): Tria nova documenta de missionibus Fr. Min. Tartariae Aquilonaris annorum 1314-1322. Textus trium novorum documentorum e Tartaria Aquilonari an. 1314-1322. Archivum Franciscanum Historicum Vol. 17, pp. 55-71.

Blochet, E. (1911): Djami el-tévarikh: histoire générale du monde par Fadl Allah Rashid ed-Din. Tarikh-i Moubarek-i Ghazani. Histoire des Mongols. II. Contenant l'histoire des empereurs mongols successeurs de Tchinkkiz Khaghan. Éditée par E. Blochet. Leiden.

Dawson, C. (1980 [1955]): The Mongol Mission: Narratives and Letters of the Franciscan Missionaries in Mongolia and China in the Thirteenth and Fourteenth Centuries. Translated by a nun of Stanbrook Abbey. Edited and with an introduction by C. Dawson. New York.

DeWeese, A. D (1994): Islamization and Native Religion in the Golden Horde: Baba Tükles and Conversion to Islam in Historical and Epic Tradition. University Park, Pennsylvania.

Failler, A.-Laurent, V. (1984): Georges Pachymèrés: Relations Historiques. I. Livres I-III. Édition, introduction et notes par. A. Failler, traduction française par V. Laurent. Paris (Corpus Fontium Historiae Byzantinae 24/3).

Ferenţ, I. (1931): Cumanii şi episcopia lor. Blaj. 
Ferenţ, I. (1981): A kunok és püspökségük [The Cumans and their bishopric]. Translated by P. P. Domokos. Budapest.

Golubovich, G. (1913): Biblioteca bio-bibliografica della Terra Santa e dell' Oriente francescano. Addenda al sec. XIII, e fonti pel sec. XIV. Vol. II. Quaracchi-Firenze.

Hautala (2014) Хаутала, Роман: Ярлык хана Узбека францисканцам Золотой Орды 1314 года: латинский текст. Русский перевод и комментрии. Золотоордынское обозрение. No. $3 / 5$, pp. $31-48$.

Jackson, P. (1990): The Mission of Friar William of Rubruck. His Journey to the Court of the Great Khan Möngke 1253-1255. Translated by P. Jackson. Introduction, notes and appendices by P. Jackson with D. Morgan. London.

Jackson, P. (2005): The Mongols and the West, 1221-1410. London-New York.

Kovács, Sz. (2009): A kunok és a kereszténység [The Cumans and Christianity]. In: Balogh, L.Kovács, Sz. (eds): Térités - megtérés. A világvallások terjedése Kelet-Európa népei között [Mission and Conversion. The spread of world religions among the people of Eastern Europe]. Budapest (Magyar Östörténeti Könyvtár 25), pp. 109-128.

Liščak, V. (2012): Italian City-states and Catholic Missions in Mongolian World of the 13th and 14th Centuries. Anthropologia Integra Vol. 3, No. 2, pp. 27-36.

Makkai, L. (1936): A milkói (kún) püspökség és népei [The (Cuman) Bishopric of Milkó and its peoples]. Debrecen.

Önnerfors, A. (1967): Hystoria Tartarorum C. de Bridia Monachi. Berlin.

Pelliot, P. (1949): Notes sur l'histoire de la Horde d'Or. Suivies de quelques noms turcs d'hommes et de peuples finissant en « ar ». Paris.

Pfeiffer, N. (1913): Die ungarische Dominikanerordensprovinz von ihrer Gründung 1221 bis zur Tatarenverwüstung 1241-1242. Zürich.

PSRL II = Полное собрание русских летописей. Ипатьевская летопись. С.-Петербург. 1908.

Redlich, O. (1894): Mitteilungen aus dem Vaticanischen Archive. Eine Wiener Briefsammlung zur Geschichte des Deutschen Reiches und der Österreichischen Länder in der zweiten Hälfte des XIII. Jahrhunderts. Hrsg. Oswald Redlich. Band II. Wien.

Richard, J. (1977): La papauté et les missions d'Orient au Moyen Age (XIII $-X V^{e}$ siècles). Rome.

Ryan, J. D. (2001): Toleration Denied. Armenia between East and West in the Era of the Crusades. In: Gervers, Michael-Powell, James M. (eds): Tolerance and Intolerance. Social Conflict in the Age of the Crusades. Syracuse, pp. 55-64, 149-156.

Spinei, V. (2008): The Cuman Bishopric - Genesis and Evolution. In: Curta, F. - Kovalev, R. (eds): The Other Europe in the Middle Ages. Avars, Bulgars, Khazars, and Cumans. Leiden-Boston, pp. 413-456.

Spuler, B. (1965): Die Goldene Horde. Die Mongolen in Rußland 1223-1502. Wiesbaden.

Székely, Gy. (1988): Egy elfeledett rettegés: a második tatárjárás a magyar történeti hagyományokban és az egyetemes összefüggésekben [An unremembered fear: the second Mongol invasion in Hungarian historical tradition and in world history context]. Századok 122/1, pp. $52-88$.

Szücs, J. (2002): Az utolsó Árpádok [The last Arpads]. Budapest.

Tănase, T. (2004-2005): Le « khan » Nogaï et la géopolitique de la mer Noire en 1287 à travers un document missionnaire: la lettre de Ladislas, custode de Gazarie. Annuario. Istituto Romeno di cultura e ricerca umanistica $6-7$, pp. 267-301.

Thackston, W. M. (1999): Rashiduddin Fazlullah's Jami 'u't-tawarikh. Compendium of Chronicles. A History of the Mongols. Trans. and Ann. by W. M. Thackston. Part 2. Cambridge. 
Theiner, A. (1859): Vetera monumenta historica Hungariam sacram illustrantia maximam partem nondum edita ex tabulariis Vaticanis. I. (1216-1352) Deprompta collecta ac serie chronologica disposita ab A. Theiner. Romae.

Tizengauzen (1884) Тизенгаузен, В. Г.: Сборник материалов относящихся к истории Золотой Орды. І. Извлечения из сочинений арабских. Санктпетербург.

Tizengauzen (1941) Тизенгаузен, В. Г.: Сборник материалов относящихся к истории Золотой Opды. II. Извлечения из персидских сочинений собранные В. Г. Тизенгаузеном и обработанные А. А. Ромаскевичем и С. Л. Волиным. Москва-Ленинград.

Vásáry, I. (1986): Az Arany Horda [The Golden Horde]. Budapest.

Vásáry, I. (2005): Cumans and Tatars. Oriental Military in the Pre-Ottoman Balkans, 1185-1363. Cambridge.

Wyngaert, A. van den (1929): Sinica Franciscana. I. Itinera et realtiones Fratrum Minorum saeculi XIII et XIV. Quaracchi and Florence. 